\title{
Between Topographical Fact and Cliché: Vienna and Austria in Shakespeare and other English Renaissance Writing
}

Manfred Draudt

\section{(2) OpenEdition \\ 12 Journals}

\section{Édition électronique}

URL : http://journals.openedition.org/shakespeare/746

DOI : 10.4000/shakespeare.746

ISSN : 2271-6424

Éditeur

Société Française Shakespeare

\section{Édition imprimée}

Date de publication : 1 novembre 2005

Pagination : $95-115$

ISBN : 2-9521475-1-5

\section{Référence électronique}

Manfred Draudt, « Between Topographical Fact and Cliché: Vienna and Austria in Shakespeare and other English Renaissance Writing ", Actes des congrès de la Société française Shakespeare [En ligne], 22 | 2005, mis en ligne le 01 janvier 2007, consulté le 03 mai 2019. URL : http://

journals.openedition.org/shakespeare/746 ; DOI : 10.4000/shakespeare.746 


\section{Shakespeare et l'Europe de la Renaissance}

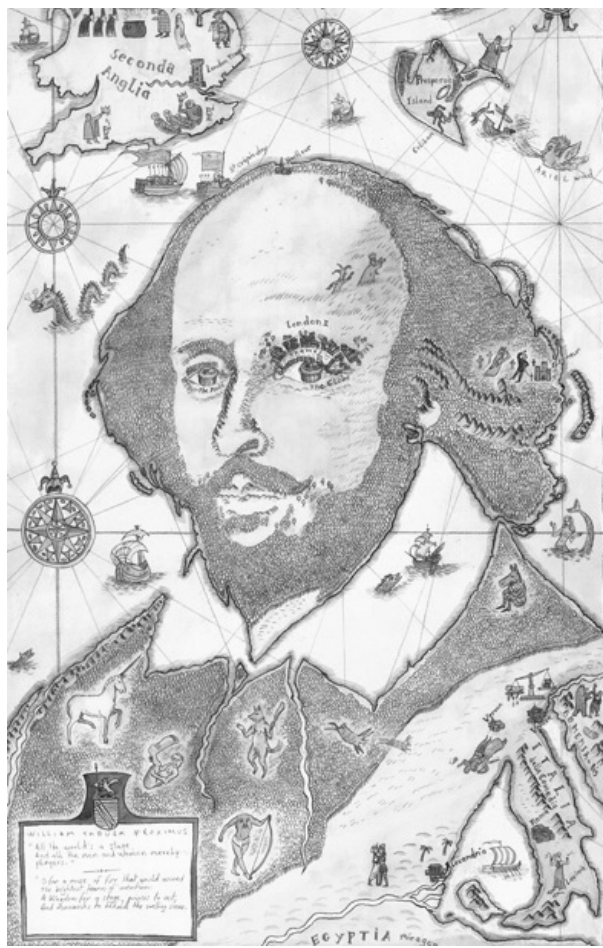

a ctes du Congrès

organisé par la

SOCIÉTÉ FRANÇAISE SHAKESPEARE

les 11,12 et 13 mars 2004

textes réunis par

Pierre KAPITANIAK

sous la direction de

Yves PEYRÉ 


\title{
COMITÉ SCIENTIFIQUE :
}

\author{
Margaret Jones-Davis \\ Jean-Marie Maguin \\ Yves Peyré \\ Pierre Kapitaniak
}

COUVERTURE :

Edouard Lekston, William Tabula Proximus, 2004

conception graphique et logo

Pierre Kapitaniak

CC 2004 Société Française Shakespeare

Institut du Monde Anglophone

Université de Paris III - Sorbonne Nouvelle

http:// univ-montp3.fr/SFS/

5 rue de l’École de Médecine

75006 Paris

ISBN 2-952 1475-1-5

Tous droits de traduction, de reproduction et d'adaptation réservés pour tous les pays 


\title{
BetWeen Topographical FaCT ANd Cliché: VIENNA AND AUSTRIA IN SHAKESPEARE AND OTHER ENGLish RENAISSANCE WRITING
}

\author{
Manfred DRAUDT
}

\begin{abstract}
Whereas English topographers related Vienna and Austria with Germany, Shakespeare sharply differentiated between the two countries. His Vienna, the location not only of Measure for Measure but also of "The Murder of Gonzago" in Hamlet, is distinctly Italian, whereas the Duke of Austria - a bragging opportunist in King John and the cousin of the French King in All's Well That Ends Well - is consistently associated with France. His profoundly negative notion of Catholic Austria is shared by Markham's "Metamorphosis" and Sampson's The Vow-Breaker. Like Marlowe in the second part of Tamburlaine, Shakespeare was careless about the (largely reliable) geographical and historical facts provided by topographers such as Ortelius, Lewkenor, Stafforde and Abbot. By contrast, Jonson in Every Man in His Humour and The Alchemist, Webster in The Devil's Law-Case and even minor authors like Munday in his Huntingdon plays and Chettle in The Tragedy of Hoffman, where Austria features prominently, showed some sense of geography and history. Moryson's travel-report An Itinerary combines the contradictory tendencies, mixing popular stereotypes and clichés with a lot of reliable information; yet it also proves perceptive in many details of "national character," which still appear to be valid to this very day.
\end{abstract}

Topographie et stéréotypes : Vienne et l'Autriche chez Shakespeare et les auteurs de la Renaissance anglaise Alors que les topographes rapprochaient Vienne et l'Autriche de l'Allemagne, Shakespeare fit une différence précise entre les deux pays. Sa Vienne, où se déroule Measure for Measure, mais aussi le "Meutre de Gonzago " dans Hamlet, est distinctement italienne, tandis que le duc d'Autriche - un opportuniste fanfaron dans King John et le cousin du roi de France dans All's Well That Ends Well - est clairement associé à la France. Sa vision profondement négative de l'Autriche catholique est partagée par Markham dans "Metamorphosis" et par Sampson dans The Vow-Breaker. Comme Marlowe dans la seconde partie de Tamburlaine, Shakespeare fait peu cas des données géographiques et historiques fournies par les topographes comme Ortelius, Lewkenor, Stafforde et Abbot. En revanche, Jonson dans Every Man in His Humour et The Alchemist, Webster dans The Devil's Law-Case et même des auteurs mineurs comme Munday dans les pièces sur Huntingdon et Chettle dans The Tragedy of Hoffman, font preuve d'une certaine connaissance de l'histoire et de la géographie. Le récit de voyage de Moryson, An Itinerary, réunit ces tendances contradictoires, en mélangeant les stéréotypes et clichés populaires avec des données fiables; toutefois il révèle de nombreux traits de " caractère national » qui semblent toujours d'acutalité aujourd"hui.

he identity of Austria in Shakespeare's day poses complex
problems. On the one hand, Austria was regarded as part of
Germany, i.e. as part of the German-speaking countries in central Europe, and the fact that the Habsburg monarch in Vienna for many centuries ${ }^{1}$ was identical with the Holy Roman Emperor contributed to blurring the distinction between Austria and Germany; on the other hand, Austria was seen throughout as a separate political entity, distinguished from its neighbouring countries: Bavaria, Saxony and Brandenburg/Prussia. All the Elizabethan topographies which

\footnotetext{
${ }^{1}$ From 1438 until 1806; there was only a brief interruption between 1740 and 1745 .
} 
appeared when Shakespeare was writing his plays reflected the view that Austria is merely one German-speaking country among many. In $A$ Discourse... of all those Cities wherein do Flourish at this Day Privileged Universities, Samuel Lewkenor discusses Vienna under the heading "The Universities of Germanie,"2 and Abraham Ortelius, who in His Epitome of the Theatre of the World ${ }^{3}$ mentions Austria among the "countries" of Germany such as "Prussia, [...] Bauaria, [... and] Switzserlande"4 even devotes a separate chapter to it:

AVSTRIA [...] is the furthest part of Germanye towards the East $[\ldots]$ the Lords whereof for the space of two hundred years have continually been Emperors of the Roman empire, which continuance in election makes it seem as though the Germayne Empire were a hereditary right belonging to their house. 5

In a similar manner Robert Stafforde in $A$ Geographical and Anthological Description of all the Empires and Kingdoms, both of Continent and Islands in this Terrestrial Globe describes Austria as "the seventh" province of Germany, "the metropolitan of which is that famous Vienna, seated upon the river Danubius, esteemed to be one of the fairest cities in Germanie."6

Shakespeare, however, differentiated sharply between Austria and Germany. Like most Elizabethans, he connected the Germans with the Danes and the Dutch, to whose notorious reputation as heavy drinkers Portia, for example, alludes: "Very vilely [I like the young German, the Duke of Saxony's nephew] in the morning when he is

\footnotetext{
2 The full title of this work which was published in London in 1600 is A Discourse, not altogether Unprofitable nor Unpleasant for such as are Desirous to Know the Situation and Customs of Foreign Cities without Travelling to See them; Containing a Discourse of all those Cities wherein do Flourish at this Day Privileged Universities. Lewkenor was a senior member of the University of Cambridge.

${ }^{3}$ London, 1603. A translation of his Theatrum Orbis Terrarum of 1570, published at Amsterdam, which Marlowe employed for his Tamburlaine. See the Introduction to Jump's edition, xiv.

4 "Under the name of Germanye are to be understood all the countries which use the Dutch tongue, which reacheth [...] from th'Alpes until the Ocean [...] it contains first Flaunders, Brabant, Hollande [...], also Danemarke, Pomerlande..."

5 "renewed and augmented by M. Coignet" $\left(32,52, \mathrm{C}^{\mathrm{v}}\right.$ [STC 18856]). With the exception of proper names, spelling and punctuation have been modernized in all quotations from topographies. Like Ortelius, George Abbot observes in A Brief Description of the Whole World (London, 1600): "the election [of the German Emperor] is tied within one hundred years unto the house of Austria" and: "That corner of Germanie which lieth nearest to Hungarie is called Austria, which is an archdukedom; fro[m] which house are come many of the princes of Germany" ("De Germania" and "De Hungaria, \& Austria", B3r [STC 25]).

${ }^{6}$ London, 1607 (11, C2 ${ }^{\mathrm{r}}$ [STC 23135]).
} 
sober, and most vilely in the afternoon when he is drunk" (I.ii.72-73). ${ }^{7}$ The image of Germany in Shakespeare's plays is not flattering; yet his notion of the Habsburg monarchy is even more profoundly negative. Typical of the Elizabethan attitude towards the Catholic arch-enemy Austria is Gervase Markham's Newe Metamorphosis from c 1600:

[...] th' Austrian greatnes [...] should quake and Spaine \& Rome [...] and if it may but to my prayer succeede Rome by’t shall die, \& Austria sore shall bleede ${ }^{8}$

The same sentiment can be found three decades later in William Sampson's play The Vow-Breaker:

We feare noe Spanish force, nor French-mens braves.

Let Austria bragge; and Rome, and Italy

Send out their poison'd Darts.

(V.iii.75)

These popular works - just like Shakespeare - do not identify Austria with Germany but rather connect it with Catholic France and Italy. Though not a pronounced anti-Catholic, Shakespeare always associated both Vienna and Austria with treachery, vice and immorality, as Ham let, Measure for Measure and King John show.

In Hamlet, Vienna is the setting of the "The Murder of Gonzago." The prince explains the "argument" of the play-within-theplay: "This play is the image of a murder done in Vienna - Gonzago is the Duke's name, his wife Baptista" (III.ii.217-18); and then he specifies: "A poisons him i'th' garden for's estate. [...] The story is extant, and writ in choice Italian. You shall see an on how the murderer gets the love of Gonzago's wife" (239-42). ${ }^{9}$ Shakespeare used an actual historical event as his model. In 1538 the Duke of Urbino, Francesco Maria I della Rovere, was poisoned by means of a lotion poured into his ears by his barber-surgeon at the instigation of Luigi Gonzaga, a kinsman of the Duchess. ${ }^{10}$ Gonzago is transformed by Shakespeare in to the victim, but his first name, Luigi, reappears in the murderer's name, Lucianus. Retaining the names and background, Shakespeare moved

\footnotetext{
${ }^{7}$ Unless specified otherwise, references to Shakespeare are to the Norton edition.

8 BL, Add. MSS 14824-14826, vol. 2, pt. 1, 255-56.

${ }^{9}$ His source, Belleforest, does not contain a play scene, but Thomas Kyd's The Spanish Tragedy - and possibly the Ur-Hamlet too - could have furnished Shakespeare with the idea of a play-within-the-play.

10 See Bullough, vol. 7, 28-31, and Jenkins, Introduction, 101-102.
} 
the scene of the murder from Urbino to Vienna, which apparently did not strike him as inconsistent with the Italian setting. "Vienna", in fact, first appears in the "good" Quarto of 1604/5" and has the ring of authenticity about it, because Q2 goes back to Shakespeare's own manuscript. It is also noteworthy that the printing of Q2 coincided with the completion of Measure for Measure, where Vienna is central.

Both in "The Murder of Gonzago" and in Measure for Measure the Viennese setting is inconsistent with the Italian local colour and names. ${ }^{12}$ In Measure for Measure all the main characters, except for Isabella, have distinctly Italian names: Vincentio, Angelo, Claudio and Juliet(ta), Lucio, and the nun Francisca. Her order, St. Clare (I.iv.5), founded at Assisi, further contributes to the Italianate ambience, as do two allusions to Rome. ${ }^{13}$ What "The Murder of Gonzago" has in common with Measure for Measure is the predominance of vice and sexual corruption, and I suspect that this is why in both cases Shakespeare deviated from his sources and chose Vienna as the setting.

Shakespeare's immediate source, Whetstone's Promos and Cassandra, transfers the scene from Cinthio's Innsbruck under Habsburg rule 14 to a city called "Iulio"15 that is associated with Matthias Corvinus, who conquered Vienna in $1485 .{ }^{16}$ Shakespeare, however, transformed Whetstone's (Hungarian) King Corvinus into the Italianate Duke Vincentio, who is at odds with the King of Hungary, ${ }^{17}$

\footnotetext{
${ }^{11}$ In Q1, the "bad" Quarto of 1603, the murder is located in "guyana," and the duke's name is "Albertus".

12 In a forthcoming article Gary Taylor suggests "Ferrara" for "Vienna" because the two names have the same number of syllables. His argument is not convincing, because he fails to take into account "The Murder of Gonzago".

13 There Vincentio has allegedly gone (III.i.338); also Brother Lodowick (the disguised Duke) claims that he has "late come from the See/ In special business from his Holiness" (III.i.445-6).

${ }^{14}$ In Hecatommithi the counterpart to Shakespeare's Duke Vincentio is the just, "most worthy" and "holy" Emperor "Massimiano" or "Maximian the Great" - the Holy Roman Emperor Maximilian I (1493-1519) - and Angelo's counterpart, "Juriste," is made governor of "Inspruchi" (see Lever's Arden edition, Appendix i, 155ff, and his Introduction, xxxviii$\mathrm{xl}$ ). For a detailed discussion of the sources of Measure for Measure see Bullough, vol. 7.

15 "Iulio" may well be identical with Vienna. According to Lewkenor, the city "was called of Ptolomey [...] Iuliobona" (F2v), and a French dictionary printed in 1670 also identifies Juliobona with "Wien, Italis Viena, urbs Pannoniae superioris" (Sjögren 27).

16 "In the Cyttie of Iulio (sometimes under the domination of Coruinus Kinge of Hungarie, and Bohemia)" in "Argument," quoted in Lever, Appendix i, 166. Born in 1443, Corvinus attacked Austria a number of times, installed a governor in Vienna, and died there in 1490.

${ }^{17}$ At the beginning of Act I, Scene ii, Lucio reports: "If the Duke [i.e. Vincentio], with the other dukes come not to composition with the King of Hungary, why then, all the dukes fall
} 
and he deliberately changed the location to Vienna, firmly establishing the new setting by nine specific allusions. Most of the references are made in the low-life scenes, so that Vienna becomes synonymous with prostitution and vice, as is suggested by the disguised Duke:

[...] here in Vienna,

[...] I have seen corruption boil and bubble

Till it o'errun the stew...

$$
(\text { V.i.311-17) })^{18}
$$

Elizabethan accounts, however, give a totally different picture of the city. In A Discourse... of all those Cities wherein do Flourish at this Day Privileged Universities (1600) Samuel Lewkenor writes that

Vienna is the most renowned metropolis and residence of the Archdukes of Austria, situate upon the shore of Danubius, a city for continuance most ancient, for wealth most opulent, and for strength most invincible, the only bulwark of the Christians against their perpetual, immane [i.e. cruel], and barbarous enemy, the Turk. (F2v)

Not caring about historical and geographical correctness, Shakespeare employed Vienna as a thinly disguised allegory of London. This is borne out by the telling character names, Froth, Abhorson and Elbow (an authentic English constable), as well as by the allegorical typenames of Mistress Overdone's customers ("young Master Rash; [...] Master Caper", etc.). ${ }^{19}$ Furthermore, Pompey's report that "All houses in the suburbs of Vienna must be plucked down" (I.ii.78) relates to an order of the Privy Council (issued in 1596) to "suppress all kinds of disorderly houses, including brothels, in the suburbs of London."20

\footnotetext{
upon the King", to which the First Gentleman replies: "Heaven grant us its peace, but not the King of Hungary's!".

18 Compare also Pompey's retort to Escalus: "Does your worship mean to geld and spay all the youth of the city? [...] If you head and hang all that offend that way but for ten year together, you'll be glad to give out a commission for more heads. If this law hold in Vienna ten year, I'll rent the fairest house in it after threepence a bay" (II.i.205-16).

19 See Lever's Arden edition, note on IV.iii.1-20. The list continues: "Master Threepile the mercer, [...] young Dizzy, and young Master Deepvow, and Master Copperspur, and Master Starve-lackey, [...] young Drop-hair [...] lusty Pudding, and Master Forthright the tilter, and brave Master Shoe-tie the great traveller, and wild Half-can [...]" (IV.iii.4-15).

${ }^{20}$ See the Introduction to Bawcutt's New Oxford edition, 2-3. Compare also a proclamation by King James of 1603 which mentions the pulling down of houses in slum areas. The rigorous law that Angelo enforces against Claudio appears to refer to Puritan extremists and writers like Philip Stubbes and Thomas Lupton, who in the $1580 \mathrm{~s}$ demanded strict measures, including the death penalty, against fornication, adultery and prostitution (see also Lever, Introduction, xlv-xlvi).
} 
In King John, it is not the location that is significant but a character, ${ }^{21}$ the Duke of Austria, who plays a prominent part in the first scenes of Acts II and III. In Shakespeare's play, the Duke of Austria is the self-styled protector of Prince Arthur and his widowed mother Constance, as well as a strong ally of the King of France, who recalls the "brave Austria['s]" feud with Richard Lionheart and their common crusade. $^{22}$ In this Third Crusade of 1189-92 the English King Richard, Philip II of France and the Austrian Duke Leopold v all participated. A chronicle reports that Leopold deserted his ally during the siege of Akkon, because Richard had insulted him and disgraced the Austrian flag by throwing it from a tower into the $\mathrm{mud}^{23}$. On his return journey, Richard was apprehended by Leopold near Vienna and taken into custody in Dürnstein. With the enormous ransom he received for King Richard (allegedly $£ 1000$ ), Leopold was able to fortify several Austrian cities, including Vienna. Both the Austrian Duke and his English adversary died in accidents: Leopold fell from a horse in 1194, and Richard was fatally wounded five years later in France when hit by a stray arrow during the siege of the castle of the Vicomte de Limoges. Yet each of the rulers soon became a figure of myth: Leopold's bloody tunic, which allegedly stayed white below his belt, became the legendary origin of the Austrian flag; and King Richard was reported to have killed a hungry lion in his prison cell by thrusting his hand down its throat and tearing out its heart, which explains his sobriquet Cœurde-lion.

Anthony Munday's The Downfall of Robert Earl of Huntingdon (1598) incongruously combines many historically correct details with the myth of King Richard and the cliché of the Duke of Austria's cowardice. The Earl of Leicester accurately recalls the humiliation of Austria during the siege of Akkon:

[...] thus did Richard take

The coward Austria's colours in his hand,

And thus he cast them under Acon walls,

And thus he trod them underneath his feet. (IV.i; p. 175, in Hazlitt).

\footnotetext{
21 [1601] Compare Bullough 11: "Shakespeare makes more of Austria in [...] II.1 so as to make his downfall later more complete".

22 Richard that robbed the lion of his heart And fought the holy wars in Palestine, By this brave duke [of Austria] came early to his grave...(II.i.3-5).

23 Probably because of a dispute over the expected booty.
} 
Also, the ransom is an issue in the dispute between Leicester and the treacherous self-styled king John: the loyal Leicester reminds John that Richard "three times sent before / To have his ransom brought to Austria" (171), which John meanly denies:

Methinks, if Richard won those victories,

The wealthy kingdoms he hath conquered

May, better than poor England, pay his ransom.

[...]

We wish King Richard well, but can send no relief.

Unexpectedly, however, Richard is reported to have returned (like a deus ex machina) and said to intend to deliver the ransom himself, like a debt of honour:

LEICESTER. Richmond! [...]

[...] welcome, dear friend!

Where is my sovereign Richard? Thou and he

Were both in Austria. Richmond, comfort me,

And tell me where he is, and how he fares.

$\mathrm{O}$, for his ransom, many thousand cares

Have me afflicted.

RICHMOND. Leicester, he is come to London,

And will himself to faithless Austria,

Like a true king, his promis'd ransom bear.

$(176-77)$

Nevertheless, most space is given to Richmond's report of King Richard's legendary feats, which are set off by Austria's cowardice. Richard's bravery is underscored by the absurd claim that he killed the son of the Austrian duke (whose name is correctly given as Leopold):

I saw King Richard with his fist

Strike dead the son of Austrian Leopold,

And then I saw him, by the duke's command,

Compass'd and taken by a troop of men,

Who led King Richard to a lion's den.

Opening the door, and in a paved court,

The cowards left King Richard weaponless:

Anon comes forth the fire-eyed dreadful beast,

And with a heart-amazing voice he roar'd,

Opening (like hell) his iron-toothed jaws,

And stretching out his fierce death-threatening paws.

[...]

I stood by treacherous Austria all the while,

Who in a gallery with iron grates

Stay'd to behold King Richard made a prey.

[...] he [Austria] shook - so help me God, he shook - 
With very terror at the lion's look.

[Leicester exclaims: "Ah, coward!"]

Richard about his right hand wound a scarf

[...]

And thrust that arm down the devouring throat

Of the fierce lion, and withdrawing it,

Drew out the strong heart of the monstrous beast,

And left the senseless body on the ground.

$(178-9)$

How Richard went free and why he should return to this pusillanimous duke to pay his ransom is left unexplained.

In the sequel, The Death of Robert Earl of Huntingdon (1598), written in collaboration with Henry Chettle, Austria features again in the allegorical dumb-show of Act I, Scene iii, even if history is turned upside down here. ${ }^{24}$

In contrast to Munday's The Downfall of Robert Earl of Huntingdon, Shakespeare in King John totally ignored basic historical facts, which he could easily have derived from sources well known to him such as John Foxe's Actes and Monuments of Martyrs. ${ }^{25} \mathrm{His}$ only concern was with the Cœur-de-lion of legend, ${ }^{26}$ and for that purpose he twisted the historical material, as he did with "The Murder of Gonzago". The Duke of Austria, who actually died before King Richard, is not only blamed for Richard's death but also accused of having stolen his trophy, the lion's skin. Like the author of The Troublesome Raigne, Shakespeare conflates England's arch-enemies, Austria and France,

24 “[...] king [John] sits sleeping, his sword by his side. Enter Austria, before whom cometh Ambition, and bringing him before the chair, King John in sleep maketh signs to avoid, and holdeth his own crown fast with both hands." Friar Tuck comments:

Ambition, that hath ever waited on King John,

Now brings him Austria, easy to be ta'en,

Being wholly tam'd by Richard's warlike hand,

And bids him add that dukedom to his crown:

But he puts by Ambition, and contemns

All other kingdoms but the English crown,

Which he holds fast, as if he would not loose (p. 252, in Hazlitt).

25 "The said Limpoldus Duke of Austrich fell in displeasure with the bishop of Rome, and died excommunicate the next yeere after, Anno 1196." Leopold was excommunicated for delivering Richard to Emperor Henry VI.

${ }^{26}$ Falconbridge, Richard's bastard son, alludes to it when justifying his mother's "sin":

Needs must you lay your heart at his dispose,

[...]

Against whose fury and unmatchèd force

The aweless lion could not wage the fight,

Nor keep his princely heart from Richard's hand.

He that perforce robs lions of their hearts

May easily win a woman's. (I.i.263-69) 
incongruously combining the Duke of Austria with the Viscount of Limoges, who, according to Holinshed, was killed by "Philip, bastard sonne to king Richard [...] in revenge of his fathers death" (Bullough iv, $28)$.

The (Catholic) Duke of Austria is stamped by Shakespeare as an enemy of England not only by his alliance with France but also by his support of Cardinal Pandulph, the Machiavellian legate from the Pope. Approving of the peace settlement between France and England, the Duke of Austria breaks the word he gave to Constance and Arthur and is therefore reviled as a turncoat:

O Limoges, O Austria[...]

[...] Thou slave, thou wretch, thou coward!

Thou little valiant, great in villainy;

Thou ever strong upon the stronger side...

(III.i.40-43)

His cowardice provokes Falconbridge to bait him with mockery, ${ }^{27}$ and his death in battle is as ignominious as it is deserved. The stagedirection reads: "Enter [the] BASTARD, with [the Duke of] Austria's head" (III.ii.0) - possibly even carrying his lion's skin as a trophy.

Although the Duke of Austria is the antithesis to the spirit of England as represented by Cœur-de-lion, Shakespeare gives him a speech in which he foreshadows John of Gaunt's glorification of England in Richard $I I .{ }^{28}$ That Shakespeare occasionally could present Austria in a positive light is borne out in a detail from the second scene of All's Well That Ends Well. There the King of France, just as in King John, is swayed by his Austrian friend and ally:

[FRENCH] KING. [...] we here receive it A certainty vouched from our cousin Austria, With caution that the Florentine will move us For speedy aid - wherein our dearest friend

27 [I] will play the devil, sir, with you,

And a may catch your hide and you alone.

You are the hare of whom the proverb goes,

Whose valour plucks dead lions by the beard.

I'll smoke your skin-coat an I catch you right...(II.i.135-40).

28 II.i.40-63. Compare Austria's opening speech:

[...] that pale, that white-faced shore,

Whose foot spurns back the ocean's roaring tides

And coops from other lands her islanders,

[...] that England, hedged in with the main,

That water-wallèd bulwark, still secure

And confident from foreign purposes... (II.i.23-28). 
Prejudicates the business, and would seem

To have us make denial.

FIRST LORD DUMAINE. His [Austria's] love and wisdom, Approved so to your majesty may plead For amplest credence...

(I.ii.4-11; my italics)

This passage that Shakespeare added to his source again illustrates his largely ahistorical, associative method of working: "Shakespeare is remembering [King] John, where Austria is the ally of the King of France."29

Primarily relying on popular legend and clichés, ${ }^{30}$ Shakespeare connects Austria solely with France (in King John and All's Well that Ends Well) and Vienna exclusively with Italy (in Measure for Measure and Hamlet). Thus he not only shows his ignorance of the actual geographical position of the country and its capital, but also fails to establish any connection between Austria and Vienna, and in fact seems to have associated the city with Venice because of the similarity in sound (a slip still commonly met in England) ${ }^{31}$ - even though the topographies of the time, such as that of Ortelius, provided reliable information:

the metropolitan of all the country [Austria] is Vienna, situated on the Danubie, the which what for the nature of th'inhabitants, [...] the stately and sumptuous building, and for the residence of the Archdukes, it may be esteemed one of the best cities of Germanye, for besides all this she is strongly seated and much famoused by the resistance she shewed unto the Turks in the year of our Lord 1526 [actually 1529] when Soliman, the Turkish Emperor, in his own person came thither with an innumerable army, since which time they have still fortified the same. It hath in it many fair churches, whereof the chief is S[t]. Stephens, of exceeding beauty, having a steeple of 480 feet high. ("Austria," $52, \mathrm{C} 3{ }^{\mathrm{v}}$ )

George Abbot, in A Brief Description of the Whole World ${ }^{32}$ (1600), similarly calls "Vienna that noble city, [...] the principal bulwark of all Christendom against the Turk, from whence Soliman was repelled," and he also mentions that Cœur-de-lion "in his return from the Holy Land was taken prisoner by the Archduke of Austria and so put to a

\footnotetext{
${ }^{29}$ H. F. Brooks quoted in Hunter's Arden edition, note on I.ii.7.

30 "[His] was a mind fully stored with the current lore," and "Current clichés could have supplied Shakespeare and his contemporaries with notions about other foreigners" (John L. Lievsay 233 and 238).

31 For Shakespeare's image of Vienna and Austria see Draudt (1993).

32 Full title: [...] Wherein are Particularly Described all the Monarchies, Empires and Kingdom s of the Same: with their Several Titles and Situations thereunto adjoining.
} 
grievous ransom" $\left(\mathrm{B}^{\mathrm{r}}\right)$. Such descriptions, but particularly Ortelius's work, may well have served as sources of information for Ben Jonson, who refers in Every Man in His Humour to the relief of Vienna from the Turkish siege. Disguised as a disabled veteran of the wars, Brainworm claims to have served for 14 years under "the best commanders in Christendom": "I was twice shot at the taking of Aleppo, once at the relief of Vienna" (II.ii.63, Folio).

The same artistic liberty - that is carelessness - regarding historical facts and chronology that we met in Shakespeare we also find in Christopher Marlowe's Tamburlaine, Part II. In the opening scene located on the banks of the Danube (the frequent mentions of which seem to prepare us for the later references to Vienna), ${ }^{33}$ Orcanes, King of [A]Natolia, promises that "Christians shall have peace"34 and negotiates a truce with his former enemy Sigismond, King of Hungary, in order to join forces against their common enemy Tamburlaine. He starts the negotiations by threatening Sigismond, who "with ... [his peers has just] crossed Danubius' stream" (79):

\section{[...] Forgett'st thou I am he \\ That with the cannon shook Vienna walls \\ [...] \\ Forgett'st thou [...] \\ That thou thyself, then County Palatine, \\ The king of Boheme, and the Austric duke \\ Sent heralds out, which basely on their knees \\ In all your names desired a truce of me?}

(I.i.86-97)

Because oaths to infidels are not binding, Sigismond and his associates, the Lords of Buda and Bohemia, break their pledge and attack Orcanes, though in the end Sigismond is defeated and killed. ${ }^{35}$

While Marlowe, in contrast to Shakespeare, links Vienna and Austria, he, too, conflates, or rather confuses, various historical figures and periods. Sigismond appears to be based on three different historical personalities: 1) the young "County Palatine" (i.e. Pfalzgraf) Philipp, one of the defenders of Vienna in the Turkish siege of 1529; 2) the Hungarian King Vladislav III, who was killed by Sultan

\footnotetext{
33 “[...] on Danubius' banks / Our warlike host in complete armour rest" (1.1.6). "Danubius" is mentioned again in $1.33,37$ and 79 .

${ }^{34}$ He specifies: "Slavonians, Almains, rutters, Muffs, and Danes," i.e. Croatians, Germans, cavalry, Swiss, and Danes (58).

35 Justly punished by God "for [...his] accurst and hateful perjury" (II.iii.3), as he confesses.
} 
Amurath II in the battle of Varna in 1444 (the circumstances of Sigismond's death in the play resembling the events that led up to the battle of Varna) $;{ }^{36} 3$ ) the historical Sigismund, who was crowned as King of Hungary in 1387 and buried as Holy Roman Emperor. As is reported in Knolles's Generall Historie of the Turckes (and also in earlier sources), King Sigismund, like Marlowe's character, crossed the Danube with his troops and re-conquered the fortress Vidina on the Danube but was defeated by Bajazeth in the battle of Nikopoli (1396). ${ }^{37}$ The conflation of different historical figures and the liberties taken with chronology resemble Shakespeare's method in King John; and Marlowe's apparent confusion of Vidina and Vienna recalls Shakespeare's likely association of Vienna and Venice.

Occasional references to Austria occur in several plays of the period, which I can mention only briefly. In Samuel Rowley's When You See Me, You Know Me, or the Famous Chronicle History of King Henry VIII (1605), Austria is one of the many titles of the Emperor Charles v, who makes his appearance towards the end of the play (Scene xv, 1. 2863ff). First Edward, the Prince of Wales, welcomes him as "great Charles the Austrian" (2892) before Henry VIII formally hails him as

Great Charles, the first Emperour of Almayne, King of the Romans, Semper Augustus, warlike king of Spaine and Cicily, both Naples, Navar and Arragon, king of Creete and great Ierusalem, Arch-duke of Austria, Duke of Millaine, Brabant, Burgundy, Tyrrell and Flanders $\left(\mathrm{K} 4{ }^{\mathrm{r}}, 1.2936-40\right)$

and awards him the Order of The Garter:

And with our George and coller of estate,

Present him with the order of the Garter:

Great Maximilian his progenitour,

Vpon his breast did wear the English Crosse,

$[\ldots]$

And Charles with knighthood shall be honoured.

$(2833-39)$

\footnotetext{
${ }^{36}$ See Fuller's edition, Notes on Dramatis Personae, 227-228. He also points out that "the connection between Sigismund and Vladislaus was probably suggested to Marlowe by Foxe's Acts and Monuments" (228).

${ }^{37}$ See Friedrich Wild, "Das Bild Wiens in der englischen Literatur bis zur Cromwellzeit" in Hietsch, i, 53-67, 60-62.
} 
The Emperor's personal meeting with the English King triggers the downfall of the ambitious and scheming Cardinal Wolsey, with which the play ends. His presumption and duplicity become apparent when Henry discovers that his intended message to the Emperor has been deliberately misrepresented by Wolsey, whose ultimate expulsion is therefore commented on by Charles v:

I feare king Henry, and my royall Vnckle,

The Cardinall will curse my progresse hether.

In John Webster's The Devil's Law-Case (1623) the illegitimate but officially acknowledged son of Charles $\mathrm{v}$ is considered as an eligible young man for an illustrious marriage:

[...] I heare her brother

Is marying the Infant shee goes with,

Fore it be borne, as if it be a Daughter,

To the Duke of Austrias Nephew...

(IV.ii.18-21)

Despite the Elizabethans' fear that Don John might have become ruler of Britain if the Spanish Armada had been successful, he is also referred to as the classic example of a brilliant bastard son:

[...] if you be a Bastard,

Such a man being your father, I dare vouch you

A Gentleman; [...]

When doe wee name Don John of Austria,

The Emperours sonne, but with reverence?

And I have knowne in divers Families,

The Bastards the greater spirits...

(IV.ii.344-51)

His fame clearly rested on his naval victory over the Turks in the battle of Lepanto, a turning point in the fight against Ottoman expansion, which was celebrated in Christian Europe and is mentioned immediately after the passage quoted. ${ }^{38}$ In Much Ado About Nothing Shakespeare might have had this historical figure in mind when calling the bastard, for whom Bandello provides neither a model nor a name, Don John. ${ }^{39}$

\footnotetext{
38 "Very well, seventie one: the Battell of Lepanto was fought in a most remarkeable time" (356-7). It was indeed fought in 1571.

${ }^{39}$ In Bandello, Piero of Argon has defeated King Carlo II of Naples (see Introduction to Zitner's Oxford edition, 7). Bullough maintains: "Perhaps the success of Shylock made Shakespeare add chiaroscuro to his comedy. So he invented Don John, bastard brother to
} 
The notoriously thick under-lip of the Habsburgs ${ }^{40}$ is mentioned a number of times, for example in Jonson's The Alchemist. In Act IV, Scene i, Doll Common, who is introduced to the credulous and lascivious Sir Epicure Mammon, immediately offers him her lip. ${ }^{41}$ So when Mammon tries to flatter her, he comes back to her lip:

There is a strange nobility i'your eye,

This lip, that chin! Methinks you do resemble

One o' the Austriac princes.

And a little later Mammon speaks of Subtle, the alchemist and Doll's companion, as

\section{[...] A man, the Emp'ror}

Has courted, above Kelly: sent his medals,

And chains, t'invite him.

Jonson, who had read widely on alchemists, also proves his knowledge of the Habsburgs. Edward Kell[e]y, born as Talbot, was invited by Emperor Rudolph II to come to Prague and to bring the philosopher's stone, but when he failed to produce gold, the chains he had been promised as rewards turned into the iron chains of a prison. ${ }^{43}$

Austria as a dramatic character also features in two other plays of the period. In Chapman's The Conspiracy and Tragedy of Charles Duke of Byron (1608) Albert, Archduke of Austria and ruler of the Spanish Netherlands, appears towards the end of Act I, Scene ii (from line 165 onwards). The son of Emperor Maximilian II and son-in-law of Philip II of Spain, he lived from 1559 to 1621 . He is an entirely nondescript character in Chapman, speaking a total of 21 lines, but his court at Brussels is the location of Byron's embassy, the signing of the

Don Pedro', 'a plain-dealing villain' and a Malcontent of a kind just emerging in satire and the theatre" (ii, 72).

${ }^{40}$ It was derived from Cymburgis of Masovia, the second wife of Ernestus of Iron (Ernst der Eiserne), who died in 1435. In his Anatomy of Melancholy (1621) Burton uses it as an example of hereditary transmission.

41 "Sir, I were uncivil / If I would suffer [...you to kiss my vesture]; my lip to you , sir" (3435). References are to Mares's edition.

42 The housekeeper Face's aside deflates this absurd flattery: "Very like, / Her father was an Irish costermonger" (56-57).

${ }^{43} \mathrm{He}$ died in 1595 after an attempt to escape. Originally Kelly had been the medium of the magician Doctor John Dee, and the two are regarded by some critics as the models for Face and Subtle (see the notes in Mares's edition and particularly the Notes as well as Appendix II in Kernan's Yale edition, 221, 243-44). 
Treaty of Vervins. At Albert's court Byron is not only "wooed and worshipped" (II.i.9) but also meets the treacherous exile d'Aumale.

In Henry Chettle's The Tragedy of Hoffman ${ }^{44}$ Austria is much more prominent: the play contains no fewer than 25 references. Lucibelle, the daughter of the (unnamed) Duke of Austria, is on stage in seven of the play's twelve scenes, and her father appears in two. ${ }^{45}$ Even if most of the characters' names appear to be fictitious, the play does reflect the geographical situation of Germany. (The Dukes of) Saxony, Prussia and Luningberg (i.e. Lüneburg) play important roles, and the mention of Pomer[n], Danzig, Lubecke, Wittenberg and Heidelberg further adds to the local colour; Austria is correctly conceived of as a distant country by the Duke of Saxony, who confers "with Princely Ferdinand [the Duke of Prussia] / About an embassie to Austria" (1504). Both the Duke of Austria and his daughter become victims of the devilish plots of the avenger, Clois Hoffman, who slanders the innocent Lucibelle (after the manner of Don John in Much Ado About Nothing) and thus contrives her (seeming) death together with that of her betrothed, young Saxony. At first enraged by the elopement of the couple, the Duke of Austria is eventually reconciled with old Saxony (II.ii), though his anger flares up again upon hearing that Saxony's second son, who was set on by Hoffman, has killed the couple. Attacking old Saxony, the Duke of Austria is ultimately slain in the scuffle by Hoffman (in the way Roderigo is murdered by Iago).

Finally, I want to consider the travel reports; of these only Fynes Moryson's An Itinerary deserves closer attention. ${ }^{46}$ Originally written

\footnotetext{
${ }^{44}$ Henslowe recorded for this play a part payment to Henry Chettle in 1602 , though the quarto was not printed before 1631. Its date is therefore doubtful, as is its authorship. It has also been ascribed to Munday.

45 Although no direct source has been identified for it, the beheading of "Hans Hofeman" at Danzig in 1580 must have been a source of inspiration (see the Introduction to Wilson's reprint, v). In the play Hans Hoffman is the name of the father who is revenged by his son.

46 Thomas Coryate in Coryate's Crudities (1611), 2 vols, comments only briefly on Austria's salt mines: "Elizabeth who was the daughter of Meinhard Earl of Tyrol and Garicia, and Duke of Carinthia, a woman much famoused amongst the historians for finding out the mines of salt in the towne of Halles near Gemunden in the higher Austria" (ii, 144). William Lithgow in The Rare Adventures and Paineful Peregrinations (1632) shows his disillusionment about Vienna:

I traced the fertile soils of [...] Carneola, and Styria even to Vienna: all which were subject to the Emperor, save a part of Carneola that groans under the Turk. Being arrived at Vienne, I found the town and the flying fame of it far different, either for greatness, strength, or wealth: for the town rising upon a moderate height circular is but of small compass without, not passing two English miles. The suburbs round about being twice as great as the town; and the strength of it is no way comparable
} 
in Latin and published in four volumes in 1617, it describes journeys undertaken between 1591 and 1597. Moryson provides a fascinating mixture of factual information in the manner of the topographies (even a genealogy of the Habsburgs; see iv, 243-65) and extensive comments on social life and national character, ${ }^{47}$ which combine perceptive observations with traditional clichés. (The same practice can be found in the generally trustworthy topographies, which occasionally propagate popular preconceptions. Commenting on the Danube and the other major rivers of Austria, Ortelius claims that they yield "great store of fish, whereof there is one sort, which are as big as a little cottage, and therefore they also in their language call them Hausen"). ${ }^{48}$

A Fellow of Peterhouse, Cambridge, Moryson "obtained license" (i, xii) from his College to travel with the purpose of surveying the different countries of Europe. "From my tender youth", he maintains, "I had a great desire to see foreign countries" (i, xii). ${ }^{49}$ Yet unlike his contemporaries, he did not aim at Italian universities only but took a great interest in Germany and also took the trouble to learn German (see i, vii-viii). He toured extensively through Europe, visiting Germany, the Low Countries, Switzerland, Denmark, Poland, and Italy, and making longer stays at Wittenberg, Prague, Heidelberg, Leyden, Padua, Venice and Constantinople. He travelled through Austria twice, going to Vienna in September 1593 and to Innsbruck in early $1596 .{ }^{50}$ I shall focus on "his descriptions of [...] social life [, which] are much more valuable than his discourses of countries where he merely passed through as an intelligent tourist and note-taker. ${ }^{\circ 1}$ Because Austria and

to a hundred cities that I have seen, neither is it for wealth so much to be admired, being depraved of seas, shipping, and navigation, having only the needful prosperity of dry land towns (L4 $\left.{ }^{\mathrm{v}}\right)$

For later reports, particularly those written in the second half of the seventeenth century, see Erwin Stürzl, "Das Österreichbild in den englischen Reisebeschreibungen des 17. Jahrhunderts" in Hietsch, i, 68-90.

${ }^{47}$ In individual chapters of book iv: "Nature and Manners," "Bodies and Wits," "Arts and Sciences," "Universities," "Language," "The Ceremonies," "Funerals," "Customs," and "Pastimes and Exercises."

48 (C3 $\left.3^{\mathrm{v}}, 51\right)$. Hausen or Beluga can be 9 metres in length and 1500 kilograms in weight, but are neither as big as a house nor typical of rivers. They live in the Black Sea and only go up river estuaries to spawn.

49 In his essay "Of Travel" (1625) Francis Bacon maintains: "Travel, in the younger sort, is a part of education; in the elder, a part of experience" (vi, 417).

50 See i, iv-vi and xii.

${ }^{51} \mathrm{I}$, Introduction, vii. He discusses Vienna and his journey through Styria and Carinthia in i, 140-45, and Innsbruck in i, 441-2. He describes Austria in the context of the "geography of Germany" in iv, 6, and "the Burgundian and Austrian league" in iv, 392-4. 
Vienna lay off the beaten track, the Itinerary contains few direct references to Austrian people and their customs. Only the Emperor and his court at Prague receive more attention. Moryson is astonished by "the great gravity the Germans use in very small matters" and repeatedly comments on the fact that "in conference at [...] meetings they use long orations [...] with much tediousness." 52 He also expresses his surprise at the fondness of titles, a habit characteristic of Austria to this day:

They give one another not only high titles among mean persons, but many of them, as it were by dozens or wholesale, so as the preface of titles is longer than the name of the bragging soldier in Plautus. (iv, 324-25)

Since Moryson regards people as a product of the influence of climate and environment, some of his descriptions reflect his preconceptions:

Both men and women in Styria and Carinthia upon the Alps have many of them great wens in their throats, bigger than their cheeks, either by drinking water running through minerals, or snow falling into the waters...(iv, 297)

Statistically goitre is not more frequent in these provinces than in other parts of Austria, but Moryson is repeating a cliché drawn from one of the earliest descriptions of Styria by Johannes Boemus (1520), which claims that the people there are disfigured by massive swellings of their necks. ${ }^{53}$

What he writes about the universities, by contrast, shows Moryson's shrewd insight into features which still characterize the Austrian (and German) university system:

The students of Germany have little learning from private reading, but take the most part thereof upon trust (or hearsay) from the lectures of these grave professors who dictate their lectures [...] which they write out word by word (iv, 308)

He also comments on another typically Austrian attitude:

\footnotetext{
52 Moryson criticizes long and boring speeches on various occasions (see iv, 298, 331, 343). This habit is related to the pomp and gravity that Moryson also finds typical of the Germans (see 299, 313, 324-5), as well as to their "desire of vainglory" or fame: "So as German authors [... are far from receiving money for their books but] pay a crown for the printing of each leaf, keeping the books to themselves, which they commonly give freely to friends and strangers, as it were hiring them to vouchsafe the reading thereof" (305).

53 Johannes Boemus (1520). See Stanzel 36.
} 
The gentlemen of Germany study the Civil Law, richly rewarded among them, and some become doctors thereof, but they despise all other degrees, and esteem a Master of Art no better than a pedant. This myself found in Austria, when speaking with a gentleman, and upon his wonder that I spake the Latin tongue readily, telling him I was a Master of Arts, I perceived that after he esteemed me no better than a schoolmaster (iv, 310).

In Austria, a degree in law still is more useful than any other, and though recently Master's degrees have gained in weight, socially as well as academically their prestige is still much inferior to that of a doctorate.

A pervasive leitmotif in Moryson's description of the Germans reflects a common prejudice in Elizabethan and Jacobean authors, in Shakespeare's works as well as in Thomas Nashe's Unfortunate Traveller: "All the Germans have one natural vice of drunkenness in such excess... as it stains all their natural virtues." 54 He also notes their lack of a sophisticated sense of humour ${ }^{55}$ as well as their low level of drama and acting, so that they admire even second-rate English players. In the following extract Moryson comments astutely on a performance he witnessed of Robert Brown's splinter company, which gave plays by Marlowe and Gammer Gurton's Needle at the Frankfurt autumn fair in $1592: 56$

Germany hath some few wandering comedians, more deserving pity than praise, for the serious parts are dully penned, and worse acted, and

\footnotetext{
54 IV, 290; see also 291-95, 297, 298, 304, 311, 314, 316, 322, 324, 326, 331-2, 340-42, 344, $348,351,353$. Moryson relates drunkenness to their proverbial dullness, their lack of native wit. The picture Moryson gives of the Germans' rudeness, particularly their crude amusements and language, again shows his prejudice: "The German language is not fit for courtship, but in very love more fit rudely to command than sweetly to persuade, it being an imperious, short and rude kind of speech, and such as would make our children afraid to hear it" (iv, 322).

55 See iv, 298: "their actions of mirth are only amusing after their rude manner [...] If they have fools to make them merry, they wring laughter from others by absurdity of action, as falling and breaking their shins, and by telling written tales, not by sharpness of any witty talk. Indeed they know not what a pleasant jest is, but will interpret literally after the plain words such speeches as by strangers are spoken with savoury and witty conceit, if they were taken in the sense they mean them."

56 English players toured, or rather invaded, Germany between 1585 and 1618, the outbreak of the Thirty Years' War, appearing in numerous cities and towns. Among the many English comedians there were three later colleagues of Shakespeare in the Lord Chamberlain's Men: Thomas Pope and George Bryan, later at first with the Lord Strange's Men, performing at Dresden in 1587; and Will Kempe, the famous clown, visited Germany in 1601 (apparently Münster after Cologne, Redberg [Rothenburg] and Steinfurt). Companies of English actors, in fact, became familiar figures at the Frankfurt spring and autumn fairs (see Chambers ii, 273-75, and 326).
} 
the mirth they make is ridiculous and nothing less than witty (as I formerly have shewed). So as I remember that when some of our cast despised stage players came out of England into Germany and played at Franckford at the time of the mart, having neither a complete number of actors, nor any good apparel, nor any ornament of the stage, yet the Germans, not understanding a word they said, both men and women, flocked wonderfully to see their gesture and action, rather than hear them (iv, 304).

The German drama of the time was crude, and so were the performers, who were untrained craftsmen or schoolboys, which explains the German craze for professional English actors, particularly clowns.

In his description of Vienna, Moryson gets a basic detail wrong: "the river Danow runneth... from the east to the west" (i, 140). Nevertheless, he reveals his perceptiveness again when pointing out a bad habit, with which visitors to modern Austria are still confronted, the attendants' request for high tips, which are almost compulsory. Although Moryson associates this with the Germans in general, I would call it a typically Austrian vice:

They have another custom, which being frequent, is no little charge to the passengers, namely gifts which they call 'drinckgelt', that is drinking money (as if money were for no use but drinking). And these being at first free gifts are now challenged of right. The servants in inns, though they do a passenger no service, [...] and though they give him foul sheets in his bed, yet they will challenge of him this drinking money as their due. Yea, if he go away and forget to give it, they will follow him to exact it, as if he had forgotten to pay for his diet. ${ }^{57}$

Although by no means very prominent in English minds, Austria and Vienna were perceived in a complex and contradictory way in this period. The far-off country was associated with Catholicism and many popular prejudices and clichés, particularly in the works of Shakespeare, even though reliable, if basic, geographical, historical and political facts were available from numerous topographies. Whereas dramatists like Shakespeare and Marlowe were careless about these sources of information, Jonson, Chapman and Webster and even minor authors like Munday and Chettle showed some sense of geography and

\footnotetext{
57 "Like is the practice of artisans in shops. [...] the prentices must have this drinking money, and will refuse it with scorn and reproaches, if it be not as much as they expect. [...] The very coachmen, who carry them selves very rudely to all passengers, [...] yet at the end of the journey, besides payment, will extort large drinking money, as due to them, not of courtesy but of right. Trumpeters and musicians [...] put a trencher about the table to receive this drinking money" (iv, 345-46; see also 290, 300, 341, 350).
} 
history. Moryson's travel report combines the contradictory tendencies: it mixes popular stereotypes and clichés with a wide range of reliable information, yet also proves strikingly perceptive in many details of "national character," which still seem to be valid to this day.

Manfred DRAUDT

Université de Vienne

\section{References}

Bacon, Francis. The Works. Ed. J. Spedding, R. L. Ellis, and D. D. Heath. London, 1861. Facsimile reprint Stuttgart and Bad Cannstatt: Frommann, 1963.

Bullough, Geoffrey ed. Narrative and Dramatic Sources of Shakespeare, 8 vols. London: Routledge and Kegan Paul, 1975-75.

Chambers, E. K. The Elizabethan Stage. 4 vols. Oxford: OUP 1923.

Chapman, George. The Conspiracy and Tragedy of Charles Duke of Byron. Ed. John Margeson. Manchester and New York: Manchester UP, 1988.

Chettle, Henry. The Tragedy of Hoffman. Malone Society Reprint. Ed. F. P. Wilson. Oxford: OUP, 1950.

Draudt, Manfred. "Das Wien- und Österreichbild Shakespeares". Shakespeare Jahrbuch (1993): 118-33.

Hazlitt, W. Carew, ed. A Select Collection of Old English Plays. vol. 8. $4^{\text {th }}$ ed. London: Reeves and Turner, 1874.

Hietsch, Otto, ed. Österreich und die angelsächsische Welt. Kulturbegegnungen und Vergleiche. 2 vols. Wien and Stuttgart: Wilhelm Braumüller, 1961.

Jonson, Ben. The Alchem ist. Ed. Alvin B. Kernan. New Haven and London: Yale U.P., 1974.

Jonson, Ben. The Alchem ist. Ed. F. H. Mares. London: Methuen, 1967.

Jonson, Ben. Every Man in His Humour. A Parallel-Text Edition of the 1601 Quarto and the 1616 Folio. Ed. J. W. Lever. London: Edward Arnold, 1972).

Lievsay, John L. "Shakespeare and Foreigners". In: John F. Andrews, ed. William Shakespeare: His World, His Work, His Influence, 3 vols. (New York: Scribner, 1985), i, 233-40.

Marlowe, Christopher. The Complete Works, 5 vols., v, Tamberlaine the Great, Parts 1 and 2. Ed. David Fuller. Oxford: OUP, 1998.

Marlowe, Christopher. Tamburlaine. Ed. John D. Jump. London: Edward Arnold, 1967.

The Norton Shakespeare. Ed. Stephen Greenblatt, Walter Cohen, Jean E. Howard and Katharine Eisaman Maus. New York and London: W. W. Norton \& Company, 1997 
Rowley, Samuel. When You See Me, You Know Me, or the Famous Chronicle History of King Henry VIII (1605). Malone Society Reprint. Ed. F. P. Wilson. Oxford: OUP, 1952.

Sampson, William. The Vow-Breaker, or the Faire Maide of Clifton. Ed. Hans Wallrath. Materialien zur Kunde des älteren englischen Dramas xlii. Louvain, 1914. Repr. Vaduz: Kraus, 1963.

Shakespeare, William. All's Well that Ends Well. Ed. G. K. Hunter. London and New York: Methuen, 1962.

Shakespeare, William. Hamlet. Ed. Harold Jenkins. London and New York: Methuen, 1982.

Shakespeare, William. Measure for Measure. Ed. N. W. Bawcutt. Oxford and New York: OUP, 1994).

Shakespeare, William. Measure for Measure. Ed. J. W. Lever. London: Methuen, 1965.

Shakespeare, William. Much Ado About Nothing, Ed. Sheldon P. Zitner. Oxford: OUP, 1994.

Sjögren, Gunnar. "The Setting of Measure for Measure". Revue de Littérature Comparée 35 (1961): 25-39.

Stanzel, Franz K. 'Hume, Neger' und der Steirer-Kropf". Die Presse, January 17, 2004, 36.

Webster, John. The Works. Vol. 2. Ed. by David Gunby, David Carnegie and MacDonald P. Jackson. Cambridge: CUP, 2003. 